\title{
The Implication of Spatial Ecology Dependence on Spatial Arrangement in Boundary Area
}

\author{
Werenfridus Taena ${ }^{1}$, Lala M. Kolopaking ${ }^{2,3}$, Baba Barus ${ }^{4}$, Rizaldi Boer $^{5,6}$, Bambang Juanda \\ ${ }^{1}$ Faculty of Agriculture, Timor University, Indonesia \\ ${ }^{2}$ Department of Human Ecology, Bogor Agricultural University, Indonesia 16680 \\ ${ }^{3}$ Centre Study of Agriculture and Rural Development, Bogor Agricultural University, Indonesia \\ ${ }^{4}$ Department of Soil Science, Bogor Agricultural University, Indonesia 16680 \\ ${ }^{5}$ Department of Geophysics and Meteorology, Faculty of Mathematics and Natural Science, \\ Bogor Agricultural University, Indonesiac16680 \\ ${ }^{6}$ Centre for Climate Risk and Opportunity Management in Southeast Asia and Pacific, Bogor Agricultural University, \\ Indonesia 16680 \\ ${ }^{7}$ Rural and Regional Development Planning, Bogor Agricultural University, Indonesia 16680
}

Received November 30, 2017/Accepted April 6, 2018

\begin{abstract}
Land use changes in upstream cause flooding in the middle and downstreams so that appropriate spatial planning is required. The study aims to (1) analyze the forest management in ecologycal region percpective community, unilateral and bilateral on the boundary areas of Indonesia and Timor Leste, (2) analyze dependence of spatial-ecology with income farmers, and (3) analyze descriptively the spatial planning of border regions. The data used were secondary and primary data which were obtained from Indonesia and Timor Leste. Primary data sampling were carried out by using multistage sampling, namely cluster sampling for the sample village representing the upstream, middle, and downstream of the watershed; while the sample offarmers were collected by using purposive sampling. The analysis used was descriptive which was used to analyze management of forest in ecologycal region on boundary area. Then, the spatial durbin model was used to analyze the dependence effect of spatial-ecology on farmer income in transboundary watershed. The spatial durbin model showed that farmers' income in the downstream of transboundary watershed will be reduced because patterns of farming on upperstream transboundary watershed tends to be exploitative. This implication required administrative and spatial ecology perspective in boundary spatial planning.
\end{abstract}

Keywords: land use changes, spatial-ecology dependence, boundary area, spatial planning

*Correspondence author,email:weren_ntt@yahoo.co.id,ph.: +62-388-2433012

\section{Introduction}

Development of state border areas is intended to safeguard the sovereignty of the state and reduce regional inequality. The development of border areas is carried out by improving defense and security, improving community welfare, and managing sustainable natural resource (BNPP 2010). The constraints of border development are state-based administration, and lack of perspective of functional areas (ecological, social, economic, and cultural). Izard (1975) and Hoover (1977) in Rustiadi et al. (2011) state that development should be based on the typology of a region. In general the typology of the region is classified into three categories, namely homogeneous territory, functional area, and planning area.

The Indonesian government designates boundary areas as one of the planning areas, namely as a national strategic area.
The mandate of Law Number 26 of 2007 on Spatial Planning states the national strategic area must have spatial planning as the foundation for the implementation of development. The spatial plan of the state border area in East Nusa Tenggara is determined through Presidential Regulation Numbered RI 179 of 2014. The management of Indonesia's and Timor-Leste's land borders is distributed in the western and eastern sectors. East border between the East Central Timor Regency and Kupang Regency (Indonesia) with District Oecussi (Timor Leste), in which the Timor Leste constitution is designated as a special area because of its enclave location in Indonesia.

Timor Leste as an independent state leads to the enforcement of international rules restricting the social interactions of the population in the border regions of the country. Taena et al. (2013) states that the social interactions of people in the border regions of Indonesia and Timor Leste 
are based on economic, social, and cultural reasons. Residents in the country's border region need adaptation processes in social interaction, so most of the locals engage in illegal interactions. The Government of Indonesia and Timor Leste recognize the importance of the social interactions of residents of the border areas of the country to make adjustments to the rules by imposing cross-border passages, opening up border markets, and building road infrastructure.

This policy has an impact on the increasing social interaction and its accumulation with increasing population causing increased demand for food across regions. The fulfillment of these food needs is obtained from dryland and wetland farming. Consequently, land use changes, from conservation land (forests, schrubs, and savannahs) into cultivated land (dryland farming, rice fields and settlements) in the border areas of the country. Conversion of land use is influenced by social factors as proposed by Syarif et al. (2015). Johnson (1980) states that social interaction is an effort to meet the basic needs. Higher social interaction leads to changes in land use not only in areas where an entity remains, but also causes land use changes in other neighboring areas.

Land use change is generally more common in land with individual or common ownership rights than land owned by the state. Communal land ownership generally has more open access than individuals and countries (Fauzi 2010). However, individual property is also vulnerable to misuse, compared to state ownership.

Land use changes when administered are administratively located in the border areas of the country, and functionally ecologically located in watersheds. As a result, land use changes lead to a decrease in watershed functions due to changes in the water system. The impact is a decline in farmers' income around the watershed because it uses the same water resources. Satriawan et al. (2014) stated that the distribution pattern of agricultural activities was limited by climate, hydrology, soil type, and slope. Land characteristization in the transboundary watershed distributed are dry land farming on upperstream and wetland farming in downstream.

Land use for agriculture on upstream watersheds reduces water use for agriculture in the midstream and downstream watersheds. This condition indicates the presence of sociospatial ecology due to spatial heterogeneity and spatial interregional dependence as described by Schmidtner et al. (2012). The use of water resources in the boundary areas is also common because there is no institutional arrangement regarding the distribution of water in each region. Hidalgo et al. (2015) stated socio-spatial also shows ecological and economic diversity.

The implications of spatial-ecology dependence are needed spatial planning as suggested by Scellato et al. (2011). Based on the problems presented, this study aimes to (1) analyze the forest management in ecologycal region perspective community, unilateral, and bilateral on the boundary areas of Indonesia and Timor Leste, (2) analyze the spatial-ecology dependence relationship with farmer income in transboundary watershed, and (3) analyze descriptively the spatial-ecology dependency implications of spatial arrangement of boundary areas.

\begin{abstract}
Methods
Location This research was conducted in Tono Watershed, as one of the watersheds on the boundary area of Indonesia and Timor Leste. Watershed is an ecological area in which there is socio-spatial economic interaction (Hidalgo et al. 2015). The Tono Watershed as a functional ecological area is distributed over upstream of $(72 \%)$, midlestream (17\%), and downstream (11\%). The Tono Watershed is administratively located in Timor Tengah Utara District (TTU) of Indonesia (27.43\%) and District Oecussi-Timor Leste $(72.57 \%)$, and consists of six sub-districts in Indonesia and four subdistricts in Timor Leste.
\end{abstract}

Data and sampling The study was conducted using secondary data and primary data. Secondary data are used to identify forest management in ecologycal area perspective unilateral and bilateral on boundary area. The data were obtained from the Central Bureau of Statistics of North Central Timor Regency (Indonesia) and Ministerio Administratrasaun Estatal Republica Democratica De Timor Leste. Land use data were obtained from Landsat. Secondary data were confirmed by survey data to find out land use, forest management by community institutions. Primary data on forest management were obtained from community institutions. The research sample was chosen purposively from customary leaders and community leaders in the border area including 10 Indonesians and 10 East Timorese.

Furthermore, spatial-ecology dependence analysis with farmer's income used secondary data and village-based primary data on Tono Watershed. Secondary data were in the form of distance data between villages. Primary data needed were the income data of farmers and labor in farming on Tono Watershed. The determination of the primary data sample was done by multi-stage sampling procedure (modified from Rahman et al. 2016). First, cluster sampling for the determination of sample villages with the criteria of villages were located in the upstream, middle, and downstream of Tono Watershed. Selected 16 villages to be sampled, consisting of 6 villages in Indonesia and 10 villages in TimorLeste. Second, the sampling of farmers was done by purposive sampling as much as 5 respondents per village, so that the total of respondents are 80 people (30 respondents Indonesia and 50 respondents Timor Leste).

Analysis The analysis was carried out in three stages. First, to analyze forest management in ecologycal area on boundary area by using descriptive analysis. Second, spatialecology dependence analysis with farmer income in Tono Watershed by using spatial Durbin model. The basic principle of spatial Durbin model is to include location factors as weighting, which is represented by distance between villages. The proximity and interrelationships between locations lead to the emergence of spatial autocorrelation phenomena. Mathematical model of spatial Durbin model which is a modification of Schmidtner et al. (2012) is shown in Equation [1]: 
$\operatorname{LnY} Y_{i j}=a+\sum b_{j} \ln X_{j}+\sum C_{k} W_{k} \ln Y_{k}+\sum \sum W_{k} \ln X_{j}+\varepsilon_{i}$

Note: $Y_{i j}=$ the farmers' income to- $\mathrm{j}$ in the-i villages, $\sum X j=$ the amount of labor, fertilizer, seed from the-j, In the-i villages, $\sum \mathrm{b}_{\mathrm{j}} \ln \mathrm{X}_{\mathrm{j}}=$ multiple regression model, $\mathrm{W}_{\mathrm{k}}=$ distance with villages (meters), $\sum \mathrm{C}_{\mathrm{k}} \mathrm{W}_{\mathrm{k}} \ln \mathrm{Y}_{\mathrm{k}}=$ spatial auto-regression spatial model, $\sum \sum \mathrm{W}_{\mathrm{k}} \ln \mathrm{X}_{\mathrm{j}}=$ Spatial durbin model

Third, the implications of spatial-ecology dependence on spatial arrangement of border regions of the country was analyzed by using descriptive analysis. Descriptive analysis was conducted on spatial document in Indonesia, while document of spatial arrangement in Timor Leste has not existed yet. The spatial documents in Indonesia analyzed were Presidential Regulation Numbered 179 of 2014 on the State Border Area Spatial Plan in East Nusa Tenggara, and North Central Timor Regency Regulation Numbered 19 of 2008 about Spatial Planning of North Central Timor Regency Regulation 2008-2028.

\section{Results and Discussion}

Tono Watershed is a ecologycal region which is used for forest (1.26\%), open land (2.05), settlement (1.03), dry land farming (10.07), mix dry land farming (42.39), savanna (11.91), paddy fields (2.48), shrub (25.53), shrub and swamp (0.07), and body of water (3.20). Conservation land use are in a form of forest (1.26\%) and shrub (25.53\%) which decreased from $40.35 \%$ (shrub) and $1.31 \%$ (forest). The total conservation land decreased from $41.66-26.79 \%$. This condition indicates the development in the cultivated land which was converted from conservation land on hinterland area (Ikramullah et al. 2011). Conservation lands (forests and shrub) on boundary areas have three functions namely economic, social, and environmental purposes.

Forests function economically because they are utilized by the inhabitants of the border region to obtain forest products such as honey, acids, and firewood. Honey timor is one of the most well-known forest products that have good economic value. The increase of the number of people in the boundary area of the country increases the land need for settlements and agriculture to meet the needs, and it results in conversion of conservation land into cultivated land. Ningal, et al. (2013) says population growth of $90 \%$ increases the size of agriculture by $55 \%$, which is converted from conservation land (e.g. forest).

Forests function socially because generally the people of the boundary region have forests and water that are sacred. Indigenous ceremonies are conducted by tribes in the boundary region as a form of protection against forest and water resources, as border communities also realize that forests can serve to preserve the environment, especially to preserve water resources. The impacts result in different resilience between regions, including upstream farmers compared to farmers in the midlestream and downstream watersheds (if grouped according to ecological functional areas), as suggested by Azzahra et al. (2015), so it works ecologycally.

Forests in the border areas of the state are managed jointly by communities, each country separately (unilateral), and inter-state cooperation (bilateral). This grouping is based on
North (1990) which states that management is done formally and informally, while Kasper et al (1998) states that natural resource management (including forests) is conducted internally by communities and externally by national and international governments.

Society Forest management in the broad sense by society is done through agreement on spatial arrangement. Village and/or village spaces are grouped into residential areas, farming areas, livestock grazing areas, forest, and water conservation areas. The classification is carried out by the king (usif) through his representatives at the village level (e.g: Temukung and Tobe). Especially for forest and water, it is customary ceremony banul/tarabandu to maintain its sustainability. Management by society establishes order in society which is a form of social capital. Trust among the border area communities shows a socio-spatial dependence as Bærenholdt et al. (2002) states. This condition indicates that the development in the (center) area should be followed by improvement of development in the another (hinterland) area (Ikramullahet al. 2011).

Unilateral Community forest management is further formalized by the government aimed at directing individual behavior, toward the desired direction by society in reducing opportunistic behavior, and increasing certainty and regularity in society (Ostrom 1990). Unilateral forest management is undertaken through the enactment of regulations governing guidelines and managing agencies. The Indonesian government manages forests by establishing regulations in Indonesia, as does the Timor-Leste government managing forests in accordance with regulations in the country. The rules of Indonesia that can be introduced into watershed management on boundary area is the Law Numbered 26 of 2007 which states a region must have $30 \%$ green space on urban area, and ecologycal area must have $30 \%$ conservation area (forest and others, ex: shrub).

Bilateral Community and unilateral forest management synchronization is done through bilateral forest management. The community continues to undertake efforts to protect and manage forest and water resources. The Government of Indonesia and Timor-Leste prepare regulations and development programs that support forest management. The bilateral institutions coordinate the implementation and supervision. Demsetz (1967) and Allen (2002) declare that bilateral management was a solution to manage the right property of the imperfect frontier natural resources. A summary of forest management by communities, unilateral and bilateral in border areas of Indonesia and Timor Leste is shown Table 1.

Bilateral forest management has not been institutionalized in the Joint Border Committe (JBC) of Indonesia and Timor Leste. The committees in JBC Indonesia and Timor Leste only manage specific resources relating to river water management that are more secure than non-welfare and environmental sustainability. The river water management committee on JBC should cover a 
Table 1 Summary of forest management on ecologycal area perpective community, unilateral, bilateral on boundary areas of Indonesia and Timor Leste

\begin{tabular}{|c|c|c|c|c|}
\hline Stakeholders & Management & Action plan & Object and location & Outcome \\
\hline \multirow[t]{2}{*}{ Community } & $\begin{array}{l}\text { Local management (local } \\
\text { wisdom) }\end{array}$ & Traditional ceremonies & $\begin{array}{l}\text { Forestry, water resources } \\
\text { on boundary area }\end{array}$ & $\begin{array}{l}\text { Sustainability of forest } \\
\text { and water }\end{array}$ \\
\hline & & Rural & $\begin{array}{l}\text { residential areas, grazing } \\
\text { farms, forest and water } \\
\text { conservation }\end{array}$ & $\begin{array}{l}\text { Equity and } \\
\text { environmental } \\
\text { sustainability }\end{array}$ \\
\hline \multirow[t]{2}{*}{ Unilateral } & $\begin{array}{l}\text { Forest and watershed } \\
\text { management }\end{array}$ & $\begin{array}{l}\text { Watershed protect and } \\
\text { management planning }\end{array}$ & $\begin{array}{l}\text { Watershed in the } \\
\text { boundary area }\end{array}$ & $\begin{array}{l}\text { Sustainability of forest } \\
\text { and water }\end{array}$ \\
\hline & $\begin{array}{l}\text { Boundary area } \\
\text { management }\end{array}$ & $\begin{array}{l}\text { Grand design of } \\
\text { boundary area } \\
\text { management }\end{array}$ & Boundary area & $\begin{array}{l}\text { The growth of } \\
\text { community welfare }\end{array}$ \\
\hline Bilateral & JBC RI-TL & $\begin{array}{l}\text { Agreement of economic, } \\
\text { pass for cross border, } \\
\text { natural resource } \\
\text { management }\end{array}$ & $\begin{array}{l}\text { Market boundary, } \\
\text { Pass for cross border }\end{array}$ & $\begin{array}{l}\text { Increased flow of goods } \\
\text { and people }\end{array}$ \\
\hline
\end{tabular}

broader range of watershed including forests and other natural resources within the watershed.

Spatial-Ecology dependence relationship with farmer's income Land use changes in Tono Watershed caused a change in water system. Upstream land use changes cause upstream, midstream and downstream of the Tono Watershed due to their ecological linkages. Similarly, exploitative upstream activities in the upstream sector will cause high surface flows and cause flooding during the rainy season especially in the midstream, and downstream watersheds. Shin et al. (2007) stated that farming is heavily influenced by water resources, so rural people working in the agricultural sector tend to choose easier access to water resources for increased production.

The result of spatial-ecology dependence analysis with farmer income in Tono Watershed is as follows:

$\mathrm{Y}=20.112-3.95 w \mathrm{Y}-7.78 w \mathrm{wtk}$

F-test shows the neighboring population (wY) and the total labor force of the neighboring region (wBtk) significantly affects the income increase in a region $(\mathrm{Y})$ at a level significant of 5\%. The results of the analysis show that there are spatial-ecology and socio-spatial interactions as proposed by Calvacanti et al. (2009).

Partially, increase the income of neighboring village farmers (wY) by 1 percent will reduce the income $(\mathrm{Y})$ an area of $3.95 \%$ at the significant level at $\alpha=0.10$. This phenomenon shows the existence of spatial-ecology dependence from the activities of farming in the transboundary watershed. Dryland farming activities are exploited in the upstream and midstream (with slash-burn systems) result in flooding during the rainy season and drought during the dry season, which is more perceived by farmers in downstream. The implications are needed spatial planning covering upstream, midstream, downstream watershed areas including water basins (Kodoatie et al. 2010). Utilization of agricultural land with agroforestry system will reduce the flooding during the rainy season and drought during the dry season, resulting in increased income of farmers in the upstream, midstream, and downstream watershed simultaneously.

An increase in the area of dry land agriculture has given an impact on the environment, since dryland farming was converted from scrubland that has more conservationfunctional land cover. The impact is a decline in the quality of the environment and the decline of farmers' income in the Tono watershed. Spatial configuration design is required as proposed by Sailer et al. (2015).

Implications of land use changes and spatial ecological watershed dependence to spatial planning of boundary areas Development of border areas increases the number of people in a region, then causes changes of land uses especially dry land agriculture due to the increase of food needs. Demand of food needs also comes from other neighboring areas causing land use change in neighboring areas. The implications of this model are sustainable land use in the management of watershed which also accommodate socio-cultural, economic and ecological interactions (Yu et al. 2003).

Land use and spatial-ecology dependence have implications for spatial arrangement in boundary areas. Spatial arrangement is directed at maintaining, controlling floods, and increasing rainwater catchment so that it is utilized during the dry season to increase farm productivity. Co-management of watershed management is required for sharing power between government and communities in the border areas of the country. Darmawan et al. (2005) states that co-management is categorized into three models (1) Ostrom model that incorporates common property into formal ownership systems, (2) Vertical Harvard Poncas models that distribute ownership rights in government hierarchy, and (3) Existence model which advocates the existence of administrative territory in accordance with ecological limits.

Law Numbered 26 of 2007 states that spatial arrangement consists of planning, utilization, and control of space. Spatial 
arrangement directs stakeholders in space activities (space utilization) and provides the basis for government and communities to participate in spatial control in the border areas of Indonesia and Timor Leste.

\section{Spatial planning in the border areas of Indonesia and} Timor Leste

\section{Space structure}

The Indonesian government designates an Indonesia's border region with Timor Leste as a National Strategic Area. The elaboration of Presidential Regulation Numbered 179 of 2014 is applied in Spatial Planning Boudary Area of Indonesia in East Nusa Tenggara Province. Spatial structure indicates a hierarchy between the national strategic activity center (Kefamenanu and Atambua) with the center of local activities. Its administrative sub-districts are located at state borders (in accordance with Law Numbered 43 of 2008 on State Territory), while ecologically, they are located in the transboundary watershed.

However, the space structure which explains in Presidential Regulation No. 179 of 2014, is less perspective of spatial-ecology dependence, while there are natural resources that cross the country. It needs spatial arrangements that accommodate ecological and administrative areas (Sirojuzilam 2007).

The implication is that spatial-ecological dependence is required, which also indicates socio-spatial interaction. Aminah (2012) states socio-spatial approach is used to reflect social, economic and political conditions in spatial planning. Political cooperation between the governments of Indonesia and Timor-Leste is needed to realize the spatial-ecology dependence of spatial planning in the transboundary area of Indonesia and Timor-Leste.

2 Spatial patterns

The pattern of spatial boundary areas of the country is in accordance with the North Central Timor Regency Regulation Number 28 of 2008 on Spatial Plan of the North Central Timor District Regency in 2008-2028. Spatial pattern consists of protected area and cultivation area. Protected area is 1.352 ha of forest area, and cultivation area is 13.313 ha (agriculture, settlement, grazing area, and open land). The balance of protected areas and cultivation areas in the spatial pattern is intended to ensure human life in the present and the future because of the interaction between environmental, economic and socio-political aspects so that development does not exceed environmental thresholds (Suweda 2011).

\section{Space utilization in the border area of Indonesia and Timor-Leste}

\section{Space structure}

Social interaction in accordance with the planned space structure indicates the center-hinterland area. Social interaction also occurs across the country either through legal procedure or illegal procedure due to sociospatial proximity resulting in regional configuration. The configuration of the region occurs due to changes in interaction within a region with other regions (Hasan 2014); and the impact is a natural diffusion process. Kopczewska (2013) states natural diffusion occurs as the process from the core city to the suburb covers about 25-30 km, and road infrastructure development extends the range of $30 \mathrm{~km}$ to $55-60 \mathrm{~km}$.

2 Spatial patterns

Watersheds in the border areas of the country are used for extensive agricultural production activities that tend to be exploitative, thus causing changes in the use of conservation land into cultivated land. Spatial use in Indonesia on the Tono Watershed is not consistent with the spatial pattern because the planned forest area is 1,352 ha, but the existing forest land is only 589 ha (-763 ha). Conversion of forest land into scrubland and vulnerable agricultural land occurs because there are several village enclaves in forest area. Abegunda et al. (2009) stated that agricultural land use is the impact of socio-spatial interaction.

The policy directive is the consistency of spatial use in Indonesia which is expected to reduce the occurrence of floods and drought. Similarly, the use of space in Timor Leste is more functioning for conservation, especially in areas with a slope $>40 \%$ that will reduce the occurrence of floods and droughts in the Tono Watershed. Hussain et al. (2014) stated that it was necessary to develop a spatial pattern of establishing green open space at center area and conservation of farmland in hinterland areas.

Another policy directive is the utilization of space in forest areas with cultivation functions which can be allowed to the community with the agroforestry system so that it continues to function conservation. Conducting conservation and cultivation simultaneously in the agroforestry system is expected to increase farmers' production and income due to reducing flooding and drought in the Tono Watershed. It takes a socio-spatial interaction design as proposed by Sailer et al. (2015). Spatial use in administering and ecological perspective requires communication between Indonesian and Timor Leste stakeholders; to increase hydrological function. Communication can be done in Joint Border Committe (JBC) forums Indonesia and Timor Leste.

\section{Spatial control in the border area of Indonesia and Timor Leste}

1 Space structure

Increasing population also increases socio-spatial interaction, thereby increasing converted agricultural land from conservation land (Polyakov et al. 2008), which is required the control of interregional social interaction. Control of socio-spatial interactions of illegal cross-border residents has been made through cross-border passage for people living in border villages.

The spatial control mechanism according to Law Numbered 26 of 2007 about Spatial Planning which described on spatial planning documents (Spatial Planning of State Border Areas and Regency Spatial Arrangement) is the provision of incentives and 
disincentives. Incentives for parties who use space in accordance with space planning, while disincentives for parties who do not use space according to its designation. Intended space control has not been done so that inconsistency of space use with spatial planning occurs.

The policy directives are socialization and consistency in the implementation of spatial plans, including the control plan to achieve sustainable development in the border areas of the country. Tukidi et al. (2007) states that the provision of incentives and disincentives is a policy of spatial planning to realize the goals and objectives of regional development, as well as to overcome various actual problems of development.

2 Spatial patterns

Control of the development of non-directional cultivation area through the provision of incentives and disincentives is a policy of spatial planning to realize the goals and objectives of regional development, as well as to overcome various actual problems of development (Law Numbered 26 of 2007 on Spatial Planning). Incentives for parties who use space in accordance with spatial planning, while disincentives for parties who do not use space according to its designation. Intended space control has not been done so that inconsistency of space use with spatial planning occurs.

Spatial pattern which is allocated to forest land, is directed to rehabilitate again to reach more than $30 \%$ of watershed area or 16,040 ha of forest land from 53,464 ha of the Tono watershed area. In its distribution, forest area in Tono watershed in Indonesia was 4,430 ha from 14,763 ha and that in Timor-Leste was 11,610 ha from 38,701 ha. This forest serves to protect soil, water, and danger from floods and landslides (Mahmud et al. 2017). Compared with the current forest area in Tono watershed is 675 ha where 589 ha is in Indonesia and 86 ha in Timor Leste). Filatova et al. (2013) states that spatial-ecological dependence is required in integrating socio-demography, ecology, and biophysics.

The general guidance of spatial arrangement in boundary area is needed for revising spatial planning (planning, utilization and control) by incorporating watersheds as functional areas of ecologyto ensure sustainable development. The implications are the interaction design that accommodates the culture of the population in the country border region (Huang et al. 2008; Caner et al. 2013).

The general policy of spatial planning on boundary area of Indonesia and Timor Leste The policy direction of spatial border area arrangement in general is the need for revision of spatial planning (planning, utilization and control) by entering the watershed as functional area of ecology to guarantee sustainable development. The revision of spatial planning also considers the agreements between Indonesia and Timor Leste on the management of natural resources across the country.

RI-RDTL Agreement on spatial border area is arranged by determining the spatial pattern and space structure. Spatial pattern relates to the cultivation area and the protected area, whereas the spatial structure relates to the placement of activity centers and the interaction network between each activity center. Spatial pattern that is arranged in accordance with property rights because cross-country watershed is owned jointly (property right is not perfect because owned by Indonesia and Timor Leste). Heltberg (2002) state, that Indonesia and Timor Leste have common property which is unregulated. Unregulated common property resources are protected only by community membership restrictions, while conservation rules do not exist or are not enforced. Unregulated common property resources are at risk of degradation and over use if the user group is large relative to the opportunity cost of time. Regulated common property is a property where both access and conservation rules are in place. Open access and common property resources are jointly referred to as the commons (or common pool resources).

Global-local collaborations and sustainability considerations The current initiatives that have resulted from this should help establish the foundations for land-use planning and sustainable development in the reserve. However, as we examine the globalised landscape of the $21^{\text {st }}$ century, the social responsibilities of local and global environments (Jamal et al. 2007). The spatial pattern with the designation of forest land is directed to be rehabilitated again to reach more than $30 \%$ of the watershed or 16,040 ha of forest land of 53,464 ha of Tono Watershed area. In its distribution, forest area of Tono Watershed in Indonesia was 4,430 ha from 14,763 ha and Timor-Leste was 11,610 ha from 38,701 ha. The total of current forest area in the Tono Watershed is 675 ha (589 ha in Indonesia and 86 ha in Timor Leste).

Current condition of Tono Watershed area in Indonesia which can be converted to forest land of 1,352 ha. Forest area in Indonesia after rehabilitation has not reached the minimum forest area (4,430 ha). It takes an individual and communal properties to be converted. The conversion is agriculture of dry land and dryland agriculture mixing slash-burn system into agroforestry system covering 2,748 ha. Total forest area and agroforestry of Tono watershed in Indonesia after rehabilitation covering 4,838 ha or over 408 ha.

Forest land and agroforestry covering an area of 4,838 ha are all located in the upstream and middle of Tono watershed. Topography is at elevation area with slope more than $40 \%$ so that it will reduce surface flow, erosion, and flood. The increase of forest area and agroforestry will also increase rainfall due to high evapotranspiration so that in the long term it will reduce drought (Sims et al. 2010). The instrument takes advantage of the fact that among upperwatersheds which supplied the tributaries of major rivers were more likely to be protected. According to conventional wisdom, protection of the "headwatersheds" (or'headwaters") areas would improve downstream water quantity andquality. Ruhle's initial protected area planning report, for instance, identifies several upper watersheds flowing into major rivers as important sites for protection. In order to locate the head watersareas, planners would have traced water ways back to their sources using maps of the major rivers and their major tributaries. This means that localities which are close to the 

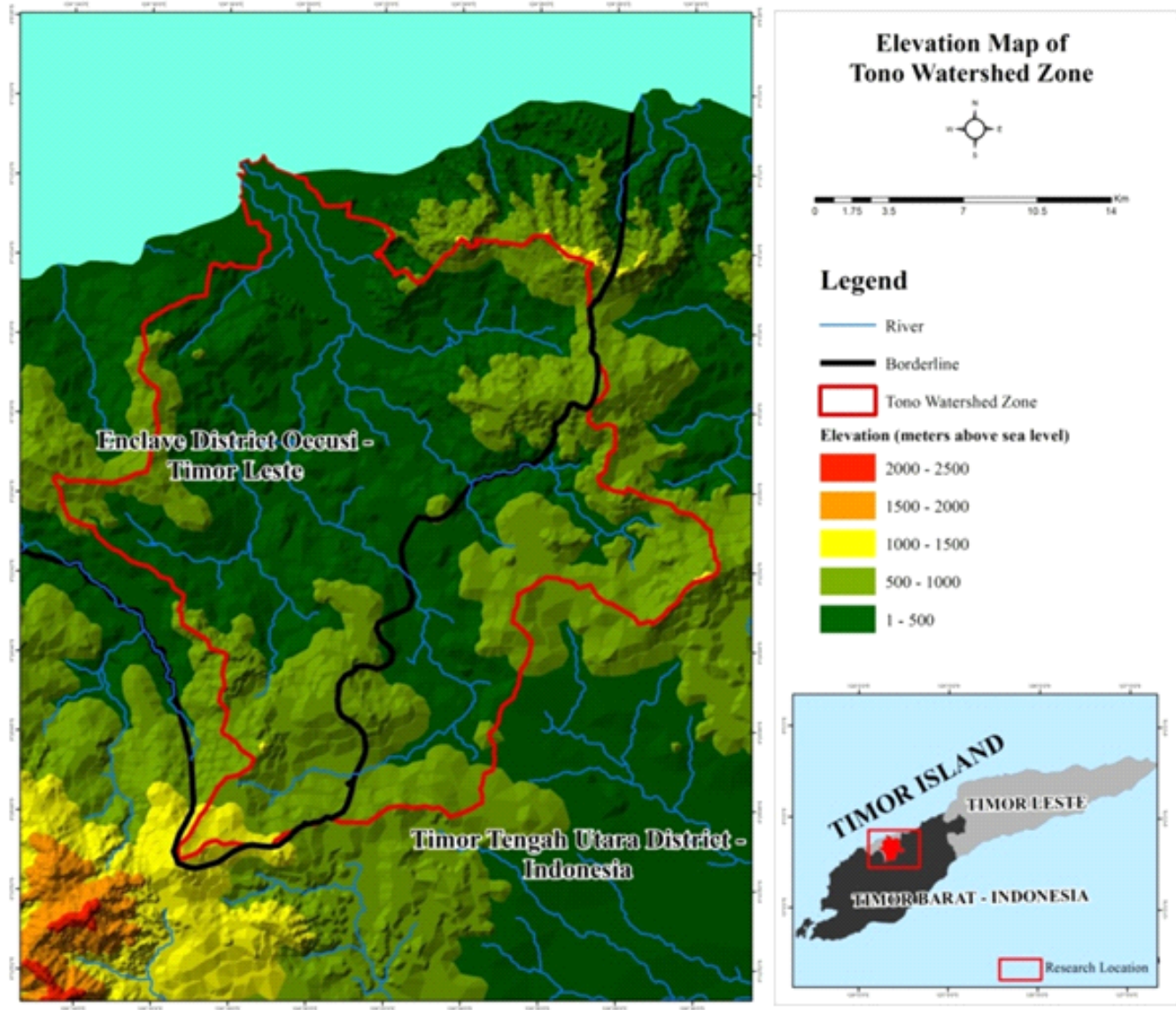

Figure 1 The Elevation of Tono Watershed (Source: Taena et al. 2016).

upper reaches of major rivers were more likely to be protected.

\section{Conclusion}

Land conversion from conservation-use land use to cultivation land is caused by development of boundary areas of the country which is represented by increasing population, infrastructure development and access to central areas). When land use changes into exploitative cultivated land (agriculture with slash-burning pattern) in the upperstream watershed, it results in a decrease in earnings in the middlestream and down stream watersheds, due to spatial-ecology dependence on the watershed.Therefore, it needs revision of spatial arrangement of the state border area with administrative perspective as well as functional area.So far, spatial arrangement is in boundary area perspective of state administration rather than in functional area perspective (spatial-ecology and socio-spatial dependence).

\section{References}

[BNPP] Nacional Boundary Management Agency of The Republic of Indonesia. 2011. Grand Design of Border Area and Boundary area Management. Jakarta: BNPP RI.
[BPS] Central of Bureua of Statistic of North Central Timor Regency. 2015. North Central Timor Regency In figure on 2014. Kefamenanu: Central of Bureua of Statistic of North Central Timor Regency.

Abegunda AA, Omisore EO, Olufunmilayo, Oluodo F, Olaleye D. 2009. Commercial horticultural practice in Nigeria: Its socio-spatial effects in Lagos city. African Journal of Agricultural Research 4(10):1064-1072.

Aminah S. 2015. Conflict and contest of Surabaya city spatial planning. Society: Journal of Sociology 20(1):59-79.

Azzahra F, Dharmawan AH. 2005. Livelihood assets effect on resilient farmer's livelihood during flood in Sukabakti villages, Tambelang Sub-District, Bekasi Regency. Sodality: Journal of Rural Sociology 03(01):19.

Calvacanti SMC, Gese EM. 2009. Spatial ecology and social interactions of jaguars (Panthera onca) in The Southern Pantanal, Brazil. Journal of Mammalogy 90(4):935-945.

Caner G, Bolen F. 2013. Implications of socio-spatial 
segregation in urban theories. Planlama 23(3):153161.

Darmawan AH, Krisnamurthi B, Tanjung D, Tonny F, Prasetyo LB, Fauzia L, Prasodjo NW, Suharno, Indrayanti Y, Mardyaningsih DI. 2004. Desentralisasi Pengelolaan dan Sistem Tata Pemerintahan Sumberdaya Alam: Daerah Aliran Sungai Citanduy. Bogor: Pusat Studi Pembangunan Institut Pertanian Bogor.

Farahani I. 2013. Vanished in gaps, vanquished in rifts: the social ecology of urban spatial change in a working class residential area, Peykan-Shahr, Tehran, Iran. Journal of Political Ecology 20:395-412.

Fauzi A. 2010. Natural Resources Economics and Environment, Theory and Applications. Jakarta: PT. Gramedia Pustaka Utama.

Filatova T, Verburg PH, Parker DC, Stannard CA. 2013. Spatial agent-based models for socio-ecological systems: challenges and prospects. Environmental Modelling \& Software 45:17.

Government of North Central Timor Regency. 2008. North Central Timor Regency Regulation No.28 of 2008 about Spatial Planning of North Central Timor Regency Regulation 2008-2028. Kefamenanu: Government of North Central Timor Regency.

Hasan E. 2014. Flexible spatial configuration in traditional houses, the case of sabzevar. International Journal of Contemporary Architecture "The New ARCH"1(1):2635.

Hetbelrg R. 2002. Property rights and natural resources management in developing country. Journal of Economic Surveys 16(2):189-214.

Hidalgo C, Ther F, Savedra G, Diaz A. 2015. Affordance of landscapes and economic socio-spatial networks in the quinchao archipelago, Chile: A contribution to landscape research and island studies. Island Studies Journal 10(1):49-70.

Huang KH, Deng YS. 2008. Social interaction design in cultural context : A case study of a traditional social activity. International Journal of Design 2(2):81-96.

Hussain NE, Abdullah N, Abdullah H. 2014. The Relationship between Rural-Urban Migration, Household Income and Unemployment: Malaysia Case Study. International Journal of Managerial Studies and Research (IJMSR) 2(8):17-24.

Ikramullah, Shair G. 2011. Economic and social dimensions of rural-urban migration in Pakistan: Results from a recent survey in the North West Pakistan. International Journal of Business and Social Science 2(3):119-126.
Jamal T, Kreuter U, Yanosky A. 2007. Bridging organisations for sustainable development and conservation: a Paraguayan Case. International Journal Tourism Policy 1(2):93-110.

Johnson DP. Classical and Modern Sociological Theory. Jakarta: PT. Gramedia.

Kopczewska K. 2013. Roads as channels of centrifugal policy transfer: A spatial interaction model revised. Contemporary Economic 7(3):39-50.

Kustianingrum D. 2010. Spatial order unplanned settlement kampung babakan Ciamis Kota Bandung. Journal Engineering LPPM Itenas 14(4):176-188.

Mahmud M, Wahyudi W, Budirianto HJ, Nugroho B. 2017. Scenarios of land-use change in protected forest of Wosi Rendani Manokwari District, West Papua, Indonesia. Journal Management Forest and Tropica 23(1):8-15.

Ministerio Administrasaun Estatal Republica Democratica De Timor Leste. 2014. Planu Estratejiku Dezenvolvimentu Districtu Oecussi. Dili: Ministru Administrasaun Estatal.

Ministerio De Agricultura E Pescas Republica Democratica De Timor Leste. 2010. Hidrology Report of Tono Irigation Area. Dili: Ministerio De Agricultura E Pescas.

National Statistic Directorat Republica Democratica De Timor Leste. 2010. Social and Economic Characteristics. Dili: National Statistic Director.

National Statistic Directorat Republica Democratica De Timor Leste. 2010. Distribuisaun Populasaun Tuir Area Administrativu. Dili: National Statistic Director.

Ningal T, Hartemink AE, Breget, AK. 2008. Land use change and population growth in the Morobe Province of Papua New Guinea between 1975 and 2000. Journal of Environmental Management 87:117-124.

Polyakov M, Zhang D. 2008. Population Growth and Land Use Dynamics along Urban-Rural Gradient. Journal of Agricultural and Applied Economics 40(2):649-666.

Public Works Department. 2007. Law Number 26 Year 2007 on Spatial Planning. Jakarta: Public Works Department.

Public Works Department. 2014. Presidential Regulation Number 179 of 2014 Concerning on Spatial Plan of State Boundary Areas of East Nusa Tenggara. Jakarta: Public Works Department.

Rahman S, Chima CD. 2016. Determinants of food crop diversity and profitability in Southeastern Nigeria: A multivariate tobit approach. Agriculture 6(14):114.

Rustiadi E, Syaifulhakim S, Panuju DR. 2011. Planning and Regional Development. Bogor: Indopress. 
Sailer K, Pomeroy R, Haslem R. 2015. Data-driven designusing data on human behaviour and spatial configuration to inform better workplace design. Corporate Real Estate Journal 4(3):249-262.

Satriawan H, Harahap EM, Rahmawaty, Karim A. 2014. Land capability evaluation for agriculture in Krueng Sieumpo watershed, Aceh. Academic Research International 5(3):55-63.

Schmidtner E, Lippert C, Engler B, Haring AM, Aurbacher J, Dabbert S. 2012. Spatial distribution of organic farming in Germany: Does neighbourhood matter? European Review of Agricultural Economics 39:661-668.

Sims KRE. 2010. Conservation and development: Evidence form the Thai protected areas. Journal of Environmental Economics and Management 60: 94-114.

Sirojuzilam. 2007. Spatial planning and regional planning. Journal Planning \& Regional Development 2(3):142149.

Suweda IW. 2011. Sustainable urban spatial planning, competitive and autonomous (A Literature Review). Scientific Journal of Civil Engineering 15(2):113-122.

Syarif E, Darjosanjoto ETS, Antaryama IGN. 2015. The coastal changes and its influence on the spatial configuration of mariso settlement, Indonesia. International Journal of Education and Research 3(3):469-482.

Taena W, Kolopaking LM, Juanda B, Barus B, Boer R. 2016. Evaluating impact of land use changes and climate variability on economic efficiency of farming in transboundary watershed of Timor Island. Environment Asia Volume 9(2):118-127.

Taena W, Rustiadi E, Himawan H. 2013. Stakeholders perception about economic development study on boundary area of North Centre Timor Regency and oecussi enclave district. Forum Pascasarjana 36(4):215232.

Todaro MP, Smith SC. 2011. Economic Development Jilid 1. Jakarta: Erlangga.

Tukidi, Hariyanto. 2007. Concept of regional development and spatial planning of Indonesia in the era of regional autonomy. Jurnal Geografi 4(1):110.

Yu CH, Chen CH, Ling CF, Liaw SL. 2003. Development of system dynamics model for sustainable land use management. Journal of The Chinese Institute of Engineers 26(5):607-618. 